\title{
Charakterystyka zmienności fenotypowej linii DH oraz mieszańców rzepaku ozimego (Brassica napus L.) pod względem cech struktury plonu
}

\author{
The characteristics of phenotypic variation in $\mathrm{DH}$ lines and hybrids of winter oilseed \\ rape (Brassica napus L.) including yield related traits
}

\section{Agnieszka Dobrzycka ${ }^{\bowtie 1}$, Joanna Wolko${ }^{1}$, Jan Bocianowski ${ }^{2}$ Kamila Nowosad $^{3}$}

\author{
${ }^{1}$ Instytut Hodowli i Aklimatyzacji Roślin — Państwowy Instytut Badawczy, Oddział w Poznaniu \\ ${ }^{2}$ Uniwersytet Przyrodniczy w Poznaniu \\ ${ }^{3}$ Uniwersytet Przyrodniczy we Wrocławiu \\ e-mail: a.m.dobrzycka@gmail.com
}

\begin{abstract}
Podczas hodowli jakościowej rzepaku (Brassica napus L.), najważniejszym etapem otrzymywania mieszańców heterozyjnych, charakteryzujących się wysokim plonem oraz dobrymi cechami jakościowymi, jest dobór zróżnicowanych linii rodzicielskich o dużym dystansie genetycznym. Celem niniejszych badań była ocena zmienności wybranych cech plonotwórczych w populacji linii podwojonych haploidów (DH) oraz dwóch populacjach mieszańców, wytworzonych przy użyciu linii CMS ogura. Obserwacje fenotypowe obejmowały analizę: długości kwitnienia, wysokości roślin, liczby rozgałęzień na roślinie, liczby łuszczyn na roślinie, długości łuszczyn, liczby nasion w łuszczynie, masy tysiąca nasion i zawartości tłuszczu w nasionach. Dla ocenionych wartości powyższych parametrów przeprowadzono analizę wariancji oraz analizę korelacji, z uwzględnieniem podziału na grupy obiektów.
\end{abstract}

\begin{abstract}
Słowa kluczowe: podwojone haploidy, zmienność fenotypowa, hodowla mieszańcowa, rzepak ozimy
During the qualitative breeding of rapeseed (Brassica napus L.), the most important stage of obtaining heterotic hybrids, characterized by high yield and good qualitative features, is the selection of diversified parental lines with a large genetic distance. The aim of this study was to assess the variability of selected yielding traits in the population of doubled haploid lines (DH) and two populations of hybrids, produced using the CMS ogura line. Phenotypic observations included analysis of: flowering duration, plant height, number of branches per plant, number of siliques per plant, silique length, number of seeds per silique, thousand seed weight, and oil content in seeds. For the above parameters, the analysis of variance and correlation analysis were performed, considering the groups of genotypes.
\end{abstract}

Key words: doubled haploids, phenotypic variation, hybrid breeding, winter oilseed rape

Rzepak ozimy (Brassica napus L.) w ciągu ostatnich 30 lat stał się bardzo ważną rośliną uprawną. Rosnące znaczenie tej rośliny wiąże się z coraz szerszym wykorzystaniem nasion rzepaku na cele spożywcze, paszowe oraz do produkcji biopaliw. Programy hodowlane koncentrują się głównie na otrzymywaniu odmian o wysokim plonie nasion oraz dobrych cechach jakościowych. Wzrost plenności uzyskuje się między innymi poprzez hodowlę odmian mieszańcowych pokolenia $\mathrm{F}_{1}$, w którym występuje zjawisko heterozji. Dobór zróżnicowanych linii rodzicielskich o dużym dystansie genetycznym jest najważniejszym etapem otrzymywania mieszańców heterozyjnych. W Polsce hodowla odmian mieszańcowych opiera się głównie na systemie męskiej sterylności CMS ogura, którego główną zaletą jest jej stabilność.

Celem niniejszych badań była ocena zmienności wybranych cech plonotwórczych w populacji linii podwojonych haploidów (DH) oraz dwóch populacjach mieszańców, wytworzonych przy użyciu linii CMS ogura.

Materiał roślinny wykorzystany w badaniach obejmował 182 obiekty: 60 linii DH, 60 mieszańców pojedynczych $(\mathrm{CMS} \times \mathrm{DH}), \quad 60$ mieszańców trójliniowych $(\mathrm{CMS} / \mathrm{DH} \times R f o)$ oraz linię rodzicielską CMS ogura i linię restorującą $R f o$, dobrane pod kątem dużego dystansu genetycznego względem linii DH. Linie DH wyprowadzono $\mathrm{z}$ mieszańca $\mathrm{F}_{1}$ pomiędzy linią o wysokiej zawartości tłuszczu a linią o wysokim plonie nasion. Mieszańce pojedyncze powstały z krzyżowania linii CMS ogura z liniami $\mathrm{DH}$, a mieszańce trójliniowe $\mathrm{z}$ krzyżowania otrzymanych męskosterylnych mieszańców pojedynczych z linią restorującą Rfo. Doświadczenie polowe prowadzono przez dwa sezony wegetacyjne (2014/15 i 2015/16) w układzie bloków losowanych $\mathrm{w}$ trzech powtórzeniach. Obserwowane cechy fenotypowe to: długość kwitnienia, wysokość roślin, liczba rozgałęzień na roślinie, 
liczba łuszczyn na roślinie, długość łuszczyn, liczba nasion w łuszczynie, masa tysiąca nasion i zawartość tłuszczu w nasionach. Dla ocenianych cech fenotypowych przeprowadzono analizę wariancji oraz analizę korelacji. W celu określenia różnic $\mathrm{w}$ zmienności cech pomiędzy poszczególnymi grupami, analizy te przeprowadzono $\mathrm{z}$ uwzględnieniem podziału na grupy obiektów.

Dla poszczególnych grup obiektów wykonano analizę zmienności. Stwierdzono dużą zmienność obserwowanych cech (współczynniki zmienności od 5,12\% do 49,80\%), a analiza wariancji wykazała, że wydzielone grupy obiektów są pod względem tych cech istotnie zróżnicowane. Czas kwitnienia był najdłuższy w grupie mieszańców $\mathrm{CMS} \times \mathrm{DH}$, a najkrótszy u roślin Rfo. Największą wysokością charakteryzowały się rośliny $\mathrm{CMS} / \mathrm{DH} \times R f o$, a najmniejszą linia restorująca $R f o$, która jednocześnie posiadała największą liczbę rozgałęzień oraz łuszczyn na roślinie.
Linia ta osiągała jednak najniższe wartości dla cech takich jak długość łuszczyn, liczba nasion w łuszczynie oraz masa tysiąca nasion. Największą masę tysiąca nasion obserwowano $\mathrm{w}$ grupie mieszańców $\mathrm{CMS} \times \mathrm{DH}$ oraz u linii $\mathrm{CMS}$ ogura. Najniższą zwartością thuszczu w nasionach charakteryzowała się grupa linii $\mathrm{DH}$, a najwyższą - mieszańce $\mathrm{CMS} / \mathrm{DH} \times$ Rfo oraz linia CMS ogura.

Istotne statystycznie dodatnie korelacje zaobserwowano pomiędzy wysokością roślin a liczbą nasion $\mathrm{w}$ łuszczynie i zawartością thuszczu, jak również pomiędzy liczbą rozgałęzień a liczbą łuszczyn na roślinie, pomiędzy zawartością tłuszczu a liczbą łuszczyn na roślinie i liczbą nasion w łuszczynie oraz pomiędzy długością łuszczyn a liczbą nasion w łuszczynie. Korelacje ujemne stwierdzono pomiędzy masą tysiąca nasion a wysokością roślin i liczbą nasion w łuszczynie. Siła korelacji w obrębie obserwowanych cech była zróżnicowana między poszczególnymi grupami obiektów.

$\underline{\text { Sponsorzy konferencji Dzień Młodego Naukowca } 2018}$

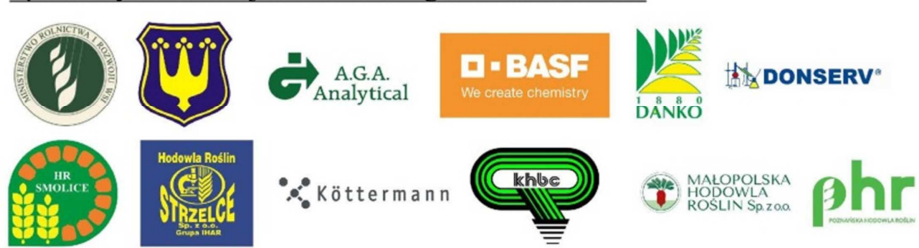

